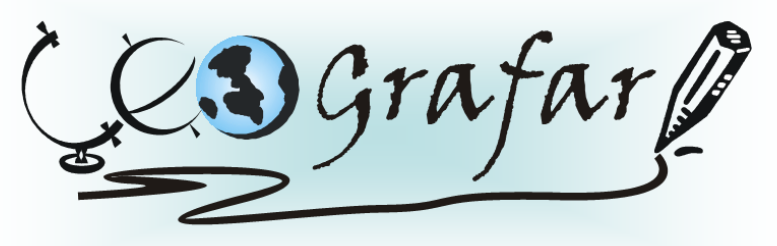

Revista Eletrônica do Programa de Pós-Graduação em Geografia - UFPR

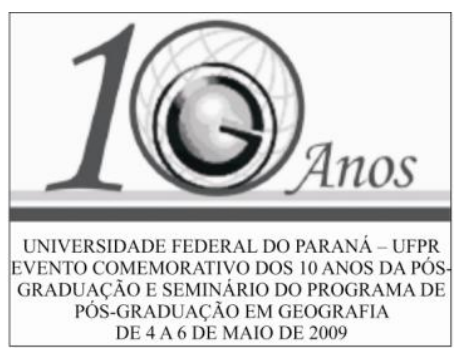

\title{
A GEOGRAFIA DO LIXO: DOS ESPAÇOS DE RELEGAÇÃO AOS DE PROXIMIDADE
}

\author{
FÁBIO DE OLIVEIRA NEVES ${ }^{1}$ \\ ANA MARIA MURATORI ${ }^{2}$
}

\section{PAISAGEM E ANÁLISE AMBIENTAL}

O que a Geografia pode informar sobre a relação dos homens com os resíduos sólidos? Mais que uma questão técnica, resolvida através da eficiência operacional ou da abundância de investimentos, o problema dos resíduos sólidos é sócio-espacial.

O lixo representa um rico tema de estudos e pesquisas sintomáticos da relação do homem com o meio. Historicamente, ele é símbolo de degradação e degenerescência dos objetos, do que não tem mais valor econômico ou afetivo, daquilo que é resultante da transformação e/ou do consumo de materiais. Os resíduos, através de sua dimensão temporal, contam a história do homem, passam a ser um signo da sociedade, do seu consumo, da sua relação íntima com o meio. Até a lixeira pode ser um objeto de estudo pela análise dos elementos que a compõem. Assim, podem-se deduzir diferentes características da vida de uma família: seus hábitos, ter indicações da renda e do tamanho da família, das profissões, do lazer e da escolaridade. O significado do lixo enquanto objeto de estudo para a Geografia ultrapassa, portanto, as questões da degradação ambiental e inserem-se numa problemática que desvenda a própria história da sociedade e da organização do espaço geográfico.

O interesse da Geografia está na inegável dimensão espacial que o lixo possui, destacando-se pela caracterização no espaço de sua presença e movimentação, pela sua produção, transporte, estocagem e eliminação. Também se revela através das paisagens marcadas pelos lixões, pela sua acumulação em terrenos baldios, nas margens dos rios e de rodovias e pela desagradável visão do lixo nos espaços públicos.

\footnotetext{
${ }^{1}$ foneves@gmail.com

${ }^{2}$ Professora orientadora
} 
Os espaços do lixo, mediados pela relação do homem com os seus resíduos e as suas representações, são os objetos desta pesquisa. Os lixões e depósitos irregulares, que apareciam no passado como o principal destino para o lixo expulso da cidade, exemplificam a tradicional representação deste como elemento repulsivo, imundo (que não devem fazer parte deste mundo). Estes espaços denotam uma relação urgente de afastamento, daquilo que deve ser mantido longe. É uma relação de repulsa marcada por estigmas, referentes tanto às pessoas que trabalham com o lixo, quanto aos espaços de destinação.

Nas últimas décadas, o redescobrimento dos resíduos sólidos como um problema eminentemente social incita novos questionamentos. A questão do lixo e a sua relação com os ideais sustentáveis do ambientalismo são temas presentes nas discussões sobre o tema. A evolução na concepção do lixo surge acompanhada de novos espaços que subvertem a marginalização e rejeição, são os espaços de reciclagem e separação, mais próximos das pessoas e da cidade. Os antigos espaços são também re-funcionalizados, tornando-se complexos sanitários tecnologicamente avançados.

Nesse contexto, é proposto fazer uma releitura da relação homem-resíduos sólidos através da Geografia e do poder de análise conferido ao espaço enquanto instância da sociedade. A leitura dos espaços do lixo é também uma leitura da relação do homem com os seus resíduos e com a cidade. Analisar-se-ão duas realidades através dos seus espaços do lixo. São elas cidades médias e gêmeas, próximas em distância, diferentes na gestão dos resíduos: Foz do Iguaçu e Ciudad del Este. 